BARBARA GIZA

Institute of Journalism and Social Communication University of Social Sciences and Humanities in Warsaw

\title{
Silent hero. The metaphorical role of the ruins of Warsaw in Polish fiction films from 1949 to 1960
}

Images vol. XXII/no. 31 Special Issue Poznań 2017 ISSN 1731-45OX

\begin{abstract}
Aвstract. Giza Barbara, Silent hero. The metaphorical role of the ruins of Warsaw in Polish fiction films from 1949 to 1960. "Images" vol. XXII, no. 31. Poznań 2017. Adam Mickiewicz University Press. Pp. 55-64. ISSN 1731-450X. DOI 10.14746/i.2017.31.06.

The article is an analysis of the image of ruins of Warsaw in Polish feature films after World War II. There is a strong tendency to connect this image with the current political (and psychological) situation, from the enthusiasm of rebuilding Warsaw just after the war to the depressive moods of the late fifties and sixties. The ruins of the city are depicted as a symbol of political and social changes in Poland in this article.
\end{abstract}

KEYwoRDs: Warsaw, ruins, World War II, architecture

The ruins of Warsaw play a special role in the Polish cinema of the 1950 . On the one hand, they serve as a testimony, or an attempt to reconcile with the wartime history of the city. On the other, they form a strong imagery with respect to the symbolically understood biography of the cinematic heroes of the time. The ruins are a silent witness, a participant of the events, they are themselves a hero. The decade in question is a peculiar time, a time of building both a new state, and also the new city of Warsaw. The symbolic changes are etched in the architectural shape of the capital. Film, which was included in the great process of rebuilding reality, illustrates said process in accordance with the ruling ideology. At the same time, film is a record of passing time, of the political and social changes and upheavals idiosyncratic for that time. The ruins become an extremely vivid symbol in the cinema of that period. They are an emotionally marked space, and thus demand to be interpreted on a par with the fates of cinematic heroes.

In my attempt at such interpretation, I will refer to Georg Simmel's essay The Ruin. The essay was published in the first decade of the twentieth century, before anyone could imagine, let alone experience, the scope of the harrowing consequences of mankind's destructive abilities, revealed during the first, and especially the Second World War. Simmel saw the ruin as a monument illustrating the greatness of bygone civilizations. In this regard his text inspires many contemporary aestheticians and architecture philosophers. Alicja Gzowska writes in her article Sic Transit Gloria Mundi:

Ruins elude definition. It is difficult to determine the moment in which buildings become ruins. Perhaps it is a process, rather than a state of being? 
They also do not possess a fixed meaning. Does the site of a devastated landscape evoke nostalgia for a past time, or shame at the damage done? Does it foment hope for a better future, or serve as a reminder of the defeat of the utopian vision? The ease with which we can assign contradictory meanings to the terms indicates perhaps that ruins lie in the eye of their beholder, and that they could not exist without this act of creative claiming. As a result, ruins often become the site of speculative strategies, which tell us more about their observers than about the ruins themselves, or their original contexts. [...] The ruin becomes a screen upon which the observer's fantasies and fears are played out, because its potential lack [of meaning] evokes an array of compensatory discursive activities. In a way then, the ruin doesn't exist.[1]

In this fragment the author reflects upon the photographs of the decaying shipyard in Gdańsk, and although Simmel's influence is evident, Gzowska also points to the symbolic role of the ruin - that of a "screen" which enables the viewer to interpret the image in a wider sense. Such a notion is especially interesting with regard to the presence of the ruins in films, on an actual screen. This will be the subject of this article. Its main goal will be to relate the ruin to contexts resulting from the destructive force of mankind revealed during the war, which in case of films set in the ruins of Warsaw, will certainly lead to interesting interpretative possibilities.

Polish feature films from the period from 1950 to 1960 are an interesting object of such a project, precisely because they were made shortly after the war, which allowed the ruins to play a significant, if not essential role. In this article I propose to analyze selected films set in the ruins of Warsaw, from the theoretical (and practical) standpoint of visual culture, which, following Simmel, regards the topos of ruins as crucial in the comprehension of the concepts of time, change and modernity. According to Simmel, the ruin

is the site of life from which life has departed. [...] the fact that life with its wealth and its changes once dwelled here constitutes an immediately perceived presence. The ruin creates the present form of a past life, not according to the contents or remnants of that life, but according to its past as such.[2]

The films will be analyzed on the basis of that premise, which I consider to be the most important part of Simmel's essay. Simmel notes that the ruin symbolizes the passing of time; the modern viewer perceives it as a testament to the old ways of life, to a life once lived, life which was formed and defined by a certain space. The image of the ruins is therefore a source of tensions between the present, the past and the future. The ruins illustrate the past and enquire about the future.

[1] A. Gzowska, "Sic Transit Gloria Mundi", <http:// pismowidok.org/index.php/one/article/view/138/192> [accessed on: 8.04.2016].

[2] G. Simmel, Ruina. Próba estetycza, in: Most i drzwi. Wybór esejów, trans. M. Łukasiewicz, Warsza- wa 2006, p. 175, also: idem, The Ruin, <http://documents.mx/documents/georg-simmel-two-essays-thehandle-and-the-ruin-558445b9112a1.html> [accessed on: 8.04.2016]. 
In this sense, the very spatial presence of ruins in a film becomes an interesting field for interpretation.

In his essay Georg Simmel noted the past character of the ruin. He writes that the ruin is "the site of life from which life has departed." This idea is further developed by Małgorzata Nieszczerzewska, who asserts that:

The history of places is really amazing, for it recalls a story about the soundless disappearing. When people live, they make places and create them, but soon there is nothing to find, not even memory. Therefore, a question appears: what is the ontological status of abandoned and forgotten places which are no longer constituted by daily, different and complex human experiences? [...] places demand certain experiences to reveal their contents and preserve their presence. Phenomenological concept of place obliges us to treat abandoned buildings not only as a material space, but first of all as a space that gathers past and present experiences. [...] The experience of a place is also related to an intimate sense of the passage of time, therefore an abstract space or a distant place is characterized by a timelessness which seems to be very important in the case of experiencing the abandoned and forgotten places.[3]

Later in the article the author notes that through subjective experiences and emotions one can develop a mutual relation with a certain space:

Sometimes a strong place attachment or identity (topophilia) can be developed, but aversion, distaste or fear of some places may appear as well (topophobia). An average user of abandoned and derelict places would probably share the latter. The material condition of place and its aesthetic values play a huge role in this negative reception. [4]

If one were to refer this observations to the Polish films of the 1950s, one has to admit that the ruins of Warsaw presented there evoke topophobia. However, the sources of topophobia differ, which is made clear once the films are analyzed chronologically. The differences lie in the perception of the ruin as a place in which the passing of life becomes evident. In earlier films the ruin is the site of the enthusiastic reconstruction of a new life, while in the films from the end of the decade they are perceived in an existential manner, and the sole existence of the new life is called into question.

Such a perception of the ruin, when applied to Polish postwar cinema, creates opportunities for interpretations which I see as potentially widening the field in which those films were understood and categorized thus far. The essential question here is the relation to time and its definition. In the films selected, the ruins of Warsaw play a powerful, or even the leading role. Moreover, they have a clearly symbolic character, creating ideologies in the philosophical, but

[3] M. Nieszczerzewska, Erasure of time. Photo-

[4] Ibidem. graphs of abandoned places, in: Politics of Erasure. From "damnatio memoriae" to alluring void, ed. A. Markowska, Warszawa-Toruń, p. 338. 
also political sense, which is significant when one considers that the wartime experiences of Warsaw had made it a symbol-city, and in the films in question one of their heroes. One is obliged to mention here the sheer totality of destruction of various elements of the city. One hundred percent of the transport infrastructure (bridges, railroads, telecommunication) was destroyed, as was more than ninety percent of the capacity of industrial, historic and cultural buildings, and around seventy percent of school and residential buildings. [5] Considering the Germans' decision to forcefully displace civilians from Warsaw and to raze the city after suppressing the 1944 Uprising, to say that in January 1945 the capital was abandoned and virtually annihilated is not an exaggerated statement. The new authorities saw the city's return to life as a symbol of constructing a new political reality. The demolished city was perceived as a symbol of the atrocities of war, and at the same time as the beginning of a new reality and the end of the old world. Kazimierz Brandys, the author of Miasto niepokonane (1946), wrote: "Warsaw was the capital city of this war," later adding that the war turned the city into

a monument of cruelty. Not one bit was spared. The city was tortured in the most horrific ways, it suffered a terrible fate, it fell into the depths of agony. No previous war had been this savage; what transpired here was unthinkable. All was war.[6]

This emotional and elevated tone testifies to the symbolic image of Warsaw as a martyr-city.

For that reason the ruins of Warsaw have been a dominant theme in Polish cinema since 1945, perhaps even the initial cinematic theme in postwar Poland. One only needs to mention Zakazane piosenki [Forbidden Songs] or Skarb [Treasure], which already in the 1940 s took an important symbolic role and created a legend. This remains true even for contemporary Polish film - the set of Miasto 44 [Warsaw '44] is open to the public and evokes strong emotions from the visitors.

Interestingly, the period from 1950 to 1960 saw a breakthrough in the symbolism of the ruins of Warsaw, which makes this decade significant. Certainly, it was a result of the political changes, but one must also admit that as more and more time elapsed since the war ended, people began to perceive the war differently. In addition, the decade in question was possibly the most dynamic because film as a medium underwent a rapid transformation towards artistic maturity.

The films selected for my analysis are: Miasto nieujarzmione [Unvanquished City], Piatka z ulicy Barskiej [Five Boys from Barska

[5] Also destroyed were: electric power plants and associated equipment - $50 \%$; electricity network $65 \%$; gas plants and gas network - 46\%; telephone switchboard service stations - 100\%; telephone cable network - 70\%; water pipelines and associated buildings - 30\%; waste management buildings $-28,5 \%$; street surfaces $-30 \%$; tram network - $85 \%$; tram and bus depots $-91 \%$; tram stock units $-75 \%$; street lamps $-98,5 \%$; stand of trees in parks $-60 \%$; total value of the zoo $-60 \%$; railway equipment within the city limits - 95\%; railway stations - 100\%; civil aviation equipment $-100 \%$; inland waterways fleet $-85 \%$. Source: <wikipedia.org/wiki/Zburzenie_Warszawy> [accessed on: 7.04.2016].

[6] K. Brandys, Miasto niepokonane, Warszawa 1972, pp. 5-8. 
Street] and Przygoda na Mariensztacie [An Adventure at Marienstadt]; Kanat [Kanal] - the high point of the Polish film school, and, finally, Eroica and Kamienne niebo [A Sky of Stone]. These productions can be divided into three groups, each characterized by its own perception of the ruins of Warsaw. This division is based on the amount of time which passed between the films' release and the end of the war, but also on the relations between life and death, the now and then, as well as the now and thereafter, which the presence of ruins signifies.

The first group consists of films produced at the beginning of the 1950s. The ruins in those films symbolize martyrdom, they represent "the heroism of Polish people, the cruelty of the Nazi occupiers, and the emphasis on Polish-Soviet friendship".[7] The films in the second group, produced in the mid-1950s, or more accurately, in the period of the Polish film school highly influenced by the works of Jerzy Stawiński, represent in great part the tragedy of the city, which is dying together with its inhabitants. The ruins of Warsaw are the most symbolic here, and the ruined city itself is a hero, perhaps even the main character. Finally, in the last group are the films produced at the end of the decade, Eroica and Kamienne niebo. The ruins in these productions serve as a background for the tragedy of human kind. They are reduced to an oppressive space which possesses a destructive power to change people's conduct.

In the first group, that is in films from the Stalin era, the ruins of Warsaw are supposed to convey the cruelty of the destroyer. At the same time they are a testament to a life reborn. The life which departed from the ruins has a symbolic bygone value, and the new life is to be born in a transformed reality. This notion corresponds with the publications of the time, which were devoted to the process of reconstruction of the capital. Grażyna Woysznis-Terlikowska wrote in her book Wczoraj dziś - jutro Warszawy (1950) that when planning the reconstruction, the architects and city planners

drew the city seemingly as it was before, and yet different. Respectful of the beauty, tradition and history of the past, yet free from its slum. A city in which everyone could live, work and rest freely. They drew a new, socialist Warsaw. The very Warsaw we build today.[8]

This group of films is characterised by an insistence on a new reality, embodied by the city's rise from ruin. Miasto nieujarzmione [Unvanquished City (1950) by Jerzy Zarzycki, is a vivid example of that. Even the title itself points to the role of the ruins, which can be seen in practically every frame the buildings and the old world had been destroyed, but those who survived, the Robinsons, are the builders of a different life in a different, new world. The destroyed city is therefore also a symbol of the destruction of the old order. Interestingly, the ini-

[7] P. Zwierzchowski, Kino nowej pamięci. Obraz II wojny światowej w kinie polskim lat 6o., Bydgoszcz 2013, p. 28.
[8] G. Woysznis-Terlikowska, Wczoraj - dziś - jutro Warszawy, Warszawa 1950, p. 98. 
tial version of the film (based on the script written by Czesław Miłosz and Jerzy Andrzejewski) was an adaptation of Władysław Szpilman's book Śmierć miasta: pamiętniki Władysława Szpilmana 1939-1945 [The Pianist: the extraordinary story of one man's survival in Warsaw, 1939-45]. It was to be a story of a man hiding in ruins of a dying city. However, at the time, the authorities deemed the film unsuitable for production, because they thought the main character to be too passive. [9] In the end, the film was not the story of a helpless young Jew, hounded, struggling to survive in a gradually destroyed city. Instead, it told a story of an able-bodied fifty-year-old man, who in fact epitomized the soldiers of the People's Army (AL), who made contacts with Soviet telegraphers. Years after the film's release, Miłosz explained that the initial idea for the script was

very realistic, it underscored the loneliness and misery of a man faced with an unfamiliar force, and that's where the title came from. The point was to make use of the incredible landscape of a city in total ruin, to show how the self-destructive actions of the civilization turned the world into a desert island, and the man into a castaway.[10]

A film based on such a script could not, however, be produced in the period which strongly encouraged and propagated creating a new and better postwar reality. The heroes of this reality were supposed to be its builders, not "ghosts" of the past.

This new reality is depicted in Alexander Ford's Piatka $z$ ulicy Barskiej [Five Boys from Barska Street, 1953]. The ruined city of Warsaw comes to life, but this life is new and there are new choices to be made. The events in the film take place in 1947 and the heroes are young boys, who, depraved by the war, try to adjust to the "normal" world. After being accused of theft, they are taken to court, but due to the absence of a witness, they cannot be sentenced to prison. They receive a suspended sentence and are given probation. Their probation officer is Wojciechowski, a workman. He is the central character in the film, a man who is noble, committed, devoted to the rehabilitation of his charges. He even finds jobs for two of them, to work on the construction of the $\mathrm{W}-\mathrm{Z}$ route. In terms of interpersonal relations, the viewer witnesses an uneven fight between the "old" and the "new" world. The film's heroes live in a ruined city, but the actual ruins are closely associated exclusively with the old, evil world of the past. This world is personified by a former commander of the underground Zenon, and by the foreman at the $\mathrm{W}-\mathrm{Z}$ route construction site, who bullies one of the boys, and who, as is revealed later in the film, is an underground saboteur. The new, kind and "clean" world is located in bright and open spaces (which is evident especially on the construction site of the $\mathrm{W}-\mathrm{Z}$ route and in the ballroom where "new" people celebrate the New Year). Conversely, the ruins are the dwelling place of accidental, sudden and pointless death,

[9] See: A. Madej, Film Miłosza i Andrzejewskiego, "Kino" 1990, no. 9.
[10] Cz. Miłosz, Wyjaśnienia po latach, “Dialog” 1984, no. 9 , p. 117 . 
accompanied by evil, deception and crime. Zenon, whose meetings with the boys take place only in the dark ruins and underground, commands that the boys blow up the $\mathrm{W}-\mathrm{Z}$ route, but they refuse. The boys are saved by their probation officer, the workman, yet the question of whether they will be able to adjust to the new world, remains unanswered.

Leon Buczkowski's Przygoda na Mariensztacie [An Adventure at Marienstadt] (1953) is also an example of the visual glorification of the new socialist reality which emerges from the ruins of the old world a reality which is white and sunny, safe and friendly. Topophobia is evident here in the resentment towards the "old" world embodied in the ruins. Chaos and uncertainty are replaced by the "new" world - a bright and clean one. The comedic convention and the romantic subplot enhance the univocally optimistic tone of the film, as does the presence of workmen who are rebuilding Warsaw. Interestingly, the physical presence of ruins in the film is scarce. The theme of reconstruction, in which the builders are considered to be the new symbol of manhood, does relate to the ruined city, yet it has an expressly positive quality in Buczkowski's film. The love between the characters and the beginning of their life together also serve as a metaphor for the glorified notion of living in a better future in a better world.

The ruins of Warsaw have a distinctly different function in Kanat (1956) and Eroica (1957), both based on Jerzy Stefan Stawiński's prose. Referring once more to Simmel's idea of the ruin as the site of life from which life has departed, it is essential to assert that both these productions focus on this "lack of life." The opening of Kanat is very telling: the long shots show the ruined city, and the following shots depict Germans burning and demolishing the ruins. Then a company of insurgents appears, with the ruins still there in the background. The off-screen voice of the narrator informs the viewer that the year is 1944, it is the end of September, and that the Warsaw Uprising is collapsing. After introducing several characters, the narrator ends with a statement: "Here are the heroes of this tragedy. Watch them closely, for these are the last hours of their lives." Therefore, from the very beginning of the film, the viewers are aware that the characters are ghosts, and they can conclude that the city itself is a ghost as well. The ruins of the city are portrayed here as devoid of life and under death's rule. Bearing in mind that the film is based on a short story by Stawiński, who was a Varsovian and a member of the uprising, one can assert that this bleak vision corresponds with his own state of mind, which probably did not change for the rest of his life. In Kanat the ruins of Warsaw are associated with chaos, death and lack of safety. They are the sole and the final tally of war. The new world of reconstruction, praised in earlier films, does not exist here. The ruins are given a deeply existential meaning. Having experienced the destruction of the city, the people, too, are destroyed. They do not exist in any new reality, for reality itself does not exist. They are lifeless, and so is the city. The only way they can experience anything is through memory, because only memory remains. 
This view presented by the Polish film school shocked the public. The viewers were used to themes of the enthusiastic, and often triumphant reconstruction of Warsaw. In Kanat they saw the overwhelming extent of the city's destruction, of its lifeless form. Above all, they saw the degradation of man, who dies a spiritual death fighting for the dying city. The insurgents are killed in combat, in the underground, or when they attempt to flee. Those who survive cannot break free. The Warsaw of Kanat is construed as a vast burial ground, a ghost-city from which there is no escape. Stokrotka and Korab are trapped by the entrance to the sewer, and once Korab manages to break free, he realizes his terrible fate. It is the fate of a former company commander who led his men to the sewer and left them there forever.

As I mentioned earlier, Kanat deeply shocked the public. It was the first postwar film which dealt with the subject of the Warsaw Uprising, and as such it was expected to provide a summary, or an essential synthesis of the events, [11] and to reassure the public that the Uprising was an undertaking which proved the ability of the Polish people to come together in rebellion, even if they had to pay for it with their own lives. But the film did not meet these expectations. Instead, it showed the characters, of which Warsaw was an important one, in tragic and cruel circumstances, which left the public shocked and disillusioned. Insurgents were not depicted as heroic figures, but as wanting and destitute, dying in the ruins of a city in agony. This vision was new and unfamiliar to Polish viewers, who thus far had been exposed to images of the enthusiastic reconstruction of the new city, the new world and new people. Kanat showed the end of the world and no one who would be able to rebuild it, which might explain why it met with such a cool reception.

The Polish film school showed interest in man and his own unique experiences, aspects which the prose of the time expressed in metaphors. The aesthetics of the Polish film school and the vision of the world which it proposed, permanently changed the Polish cinema and had a powerful influence on films produced later in the decade. This situation changed after the Central Committee Secretariat proclaimed its famous resolution on cinematography.

Andrzej Munk's Eroica (1957), set during the Warsaw Uprising, proposes a different and rather peculiar approach to the role of ruins, which in the film form the background for the events. The main character Didziuś Górkiewicz a resident of Zalesie (a suburban area of Warsaw), quite by chance becomes a messenger between the commander of a Hungarian army unit stationed in Zalesie, and the commanders of the units fighting in Warsaw. The distinguishing aspect of the film is the contrast between the image of the city, and that of the suburbs, basked in the August sun, serene and pastoral. Warsaw is fighting, it is on fire, constantly bombarded and destroyed. In Zalesie time seems

[11] See e.g. W. Bartoszewski, "Kanat” czy film o Pow-

staniu Warszawskim?, "Stolica" 1957, no. 23. 
to be standing still and nothing unusual happens. This is where the emotional power of Eroica comes to light: Warsaw falls in front of thousands of people, perhaps even in front of the whole world, and yet no one is willing to see nor to comprehend it. Initially Dzidziuś feels less than enthusiastic about his role. He is slightly amused by it, and slightly weary. It definitely has its cost - he not only risks his life, but also has to pay substantial bribes to the soldiers at the toll-gates on the city's boundaries. Once it becomes clear that his mission has failed, Górkiewicz does not stay in the safety of his home, but resolves to return to Warsaw, which can be seen burning in the distance. The fighting and collapsing city is portrayed here as a lonely martyr. It is dying as a result of poor decisions made by the Uprising commanders, the lack of good organization, and chaos, but also because of bitter irony and cruel fate.

The last film which I propose to analyze is Kamienne niebo [A Sky of Stone] (1959) by Ewa and Czesław Petelski. Set during the Uprising, it tells the story of a group of people buried in a cellar of a bombarded house. The characters are Maniuś - a petty thief, Ewa - a young girl, an unnamed woman with her small child, a resourceful landlady, and an old professor. As they continue to wait for help, they become overwhelmed by the immense pressure of the situation and turn into its victims, each in their own way. Ewa begins an affair with Maniuś, the profesor goes blind, and the landlady goes insane. The metaphorical meaning of the ruin is in a way similar to that in Kanat, yet here it is even more striking. The victims are not soldiers, but random civilians. They are trapped, the fear of death makes them lose their sanity and self-control, they succumb to their lowest instincts. There is nothing elevating about the ruins of Warsaw in Kamienne niebo. They do not promise a new world, nor do they evoke any romantic notions. Quite the contrary, in fact, they are the site of tragedy, a prison in which ordinary people lose their humanity and become animals. The ruins are hostile, ruthless and threatening, stripped of any mythological meaning. Topophobia towards the ruin is predominant. Interestingly, the relation with the city is transformed as well. While in earlier films the characters formed a symbiotic relation with the city and felt certain attachment to it, here the relation becomes one of resentment, fear and loathing.

Based on the analysis of the films selected one can make an interesting observation. Coming back to Simmel's idea a ruin as a site of life from which life has departed, we can assert that this definition is understood differently in different films. At the beginning of the 1950s, it is indeed a site of life from which life has departed, but above all it is also a promise of a new, better life. This vision is transformed by the Polish film school. The ruins from which life has departed become empty and lifeless. The city dies just as the heroes do, there is no hope for a rebirth. Still, there remains a strong feeling of attachment, the ethos of Warsaw, as it were. Films from the end of 1950 s present a vision with this ethos removed: the ruins of Warsaw are a terrifying prison, a burial 
ground which destroys innocent people. This interpretation is especially interesting considering that at the time the authorities strongly urged the filmmakers to concentrate on the present day and not on the past. During a session of the State Cinema Committee, minister Zaorski scolded the filmmakers for

the overwhelming use of 'dark themes', exhaustion of 'perverted mental attitudes' and 'solidaristic nationalism' evident [...] in films concerned with war, which unintentionally yet in an obvious manner popularize the Home Army resistance.[12]

Shown as a symbol of crushing defeat rather than victory, the ruins undoubtedly played essential role in the creation of the vision proposed in those films.

Thus, the presence of the ruins of Warsaw was undesirable and was soon replaced by the images of a modern, fully rebuilt capital. From that moment on, the city became a symbol of modernity and worldly aspirations, open to new possibilities. Yet, interestingly, the ruins of Warsaw were repeatedly portrayed in later films. This, however, should be the subject of a different analysis.

Gzowska A., Sic Transit Gloria Mundi, <http://pismowidok.org/index.php/one/ article/view/138/192> [accessed on: 8.04.2016]

Madej A., Bohaterowie byli zmęczeni?, in: Syndrom konformizmu? Kino polskie lat sześćdziesiątych, eds. T. Miczka, A. Madej, Katowice 1994

Madej A., Film Miłosza i Andrzejewskiego, "Kino" 1990, no. 9

Miłosz Cz. Wyjaśnienia po latach, "Dialog” 1984, no. 9

Nieszczerzewska M., Erasure of time. Photographs of abandoned places, in: Politics of Erasure. From "damnatio memoriae" to Alluring Void, ed. A. Markowska, Warszawa-Toruń

Simmel G., Ruina. Próba estetyczna, in: Most i drzwi. Wybór esejów, trans. M. Łukasiewicz, Warszawa 2006

Simmel G., The Ruin, <http://documents.mx/documents/georg-simmel-two-essays-the-handle-and-the-ruin-558445b9112a1.html> [accessed on:8.04.2016]

Woysznis-Terlikowska G., Wczoraj - dziś - jutro Warszawy, Warszawa 1950

Zwierzchowski P., Kino nowej pamięci. Obraz II wojny światowej w kinie polskim lat 60., Bydgoszcz 2013

[12] As cited in: A. Madej, Bohaterowie byli zmęczeni?, in: Syndrom konformizmu? Kino polskie lat sześćdziesiątych, eds. T. Miczka, A. Madej, Katowice 1994, p. 12. 